\title{
Study of Female Reproductive Performance of Sirohi Goat Managed under Farm and Field Cluster in Southern Rajasthan, India
}

\author{
Hina Ashraf Waiz ${ }^{1 *}$, Lokesh Gautam ${ }^{2}$, Mukesh Chand Sharma ${ }^{1}$ and Syma Ashraf ${ }^{3}$ \\ ${ }^{1}$ Department of Livestock Production Management, ${ }^{2}$ Department of Animal Genetics and \\ Breeding, CVAS, Vallabhnagar, Udaipur, Rajasthan, India \\ Rajasthan University of Veterinary and Animal Science, Bikaner-313601, India \\ ${ }^{3}$ Department of Education, (Natural science), Srinagar, Jammu and Kashmir, India
}

*Corresponding author

Ke y w o r d s
$\begin{aligned} & \text { Sirohi goat, } \\ & \text { Reproduction traits, } \\ & \text { Farm, Field, Cluster }\end{aligned}$
Article Info
$\begin{aligned} & \text { Accepted: } \\ & \text { 06 May } 2018 \\ & \text { Available Online: } \\ & \text { 10 June } 2018\end{aligned}$

\section{Introduction}

Goat production is an attractive livestock enterprise particularly for small and marginal farmers and landless laborers in India and in other developing countries. The success of goat husbandry largely depends on the environment where the goats are reared, and their management system. Goat is a household animal of Rajasthan. It plays an important role in livelihood of small and marginal farmers of Rajasthan as a source of cash, meat and milk
The present study was aimed to investigate the reproductive performance of female Sirohi goat managed at farm and field cluster under All India Coordinated Research Project (AICRP) on Sirohi goats, livestock Research Station LRS Vallabhnagar, LRS Bojunda (Chitorgarh), Rajsamand and Dabok areas of Udaipur, Rajasthan. The data were collected on reproductive performance on farm management and utilized for this study. The overall mean for reproduction traits viz., age at first conception, age at first kidding, weight at first conception and weight at first kidding were 444.18 $\pm 13.05,594.88 \pm 13.05$ days and 26.77 $\pm 0.21,30.90 \pm 0.18 \mathrm{~kg}$ respectively. Cluster had a significant effect on age at first conception and age at first kidding. Highly significant on weight at first conception and weight at first kidding. Age at first conception and age at kidding were highest in Farm cluster. Whereas highest weight at first conception and weight at first kidding was observed in Field cluster. It was concluded that reproductive performance of Sirohi goat were suitable and indicating efficient reproductive performance and this breed can be utilized for sustainable goat farming in southern Rajasthan. 
Reproductive efficiency of goat is considered as one of the vital factors that ensures better productivity in certain environmental conditions. It is obvious that better production efficiency can be obtained from goats when they have a high reproductive efficiency with the potentials for increased litter size and shorter generation interval specifically having higher fertility rate in comparison to other farm animals Haque et al., (2013). Reproductive efficiency of doe is determined by different processes, like age at first conception, age at first kidding etc. Sirohi is a promising dual purpose breed distributed in arid and semi-arid regions of central and southern Rajasthan. Sirohi goat is known to be famous for their excellent adaptability, fertility, meat, milk and the prolificacy of the breed is within acceptable limits. As stated earlier that reproductive efficiency is one of the important prerequisites for increasing production potential in goat, it seems rationale to investigate influence of specific environmental factor on some selective reproductive traits considering different clusters in southern Rajasthan.

\section{Materials and Methods}

\section{Experiment site}

The present study was conducted at College of Veterinary and Animal Science, Vallabhnagar, Udaipur, Rajasthan.

\section{Management of animals}

Flock was allowed to graze freely during the day time in free range grazing areas on pastures under the supervision of herdsman. On return at home goats were fed green grasses or green fodder according to the season. The formulated concentration ration was given and drinking water was provided ad libitum. Routine clinical examination and vaccination was done for herd health maintenance. Only clinically healthy goats were included in this experiment.

\section{Data collection procedure}

Data on reproductive performance of Sirohi goats were obtained from the farm and farmer's field maintained under All India Coordinated Research Project (AICRP) on Sirohi goats, livestock Research Station (LRS), Vallabhnagar, LRS, Bojunda, (Chitorgarh), Rajsamand and Dabok areas of Udaipur, Rajasthan. All the clusters are the breeding tract of Sirohi goat. The data recorded regarding age at first conception (AFC), weight at first conception (WFC), age at first kidding (AFK) and weight at first kidding (WFK) were analyzed for reproductive performances.

\section{Statistical analysis}

The data were analyzed using Mixed Model Least-Squares and Maximum Likelihood method designed by (Harvey, 1990) to study the reproductive performance across different cluster.

\section{Results and Discussion}

The overall least square means for female reproductive traits viz., AFC, WFC, AFK and WFK are presented in Table 1 and 2 respectively.

\section{Age at first conception (AFC)}

The overall least square means for age at first conception was estimated as $444.18 \pm$ 13.05days (Table 1). The results of present findings corroborated with the values reported by Singh and Roy (2003) in Jamunapari, Pathodiya (2004) in Sirohi, Rai and Singh (2005) in Jakhrana, Deokar et al., (2007) in Sangamneri, Singh et al., (2009) in Mehsana, Rao et al., (2009) in Ganjam and Yadav et al., 
(2017) in Sirohi goats. The lower figures were reported by Pathodiya (2003) in Sirohi, Yadav and Khada (2009) in crossbred of local $\mathrm{x}$ Sirohi, Sabapara et al., (2010) in Surti and Ekambaram et al., (2011) in Mahabubnagar goats respectively. However the higher results were reported by Kumar et al., (2006) in Kutchi, Patel and Pandey (2013) in Mehsana and Dudhe et al., (2015) in Sirohi goats respectively.

\section{Weight at first conception (WFC)}

The overall least squares means for weight at first conception was estimated as 26.77 $\pm 0.21 \mathrm{~kg}$ (Table 2). The results of present study fall in close range reported by Kumar et al., (2005) and Kumar et al., (2012) in Sirohi, Patel and Pandey (2013) in Mehsana goats. However the results recorded in current study for WFC were higher than the results reported by Patel (2005) in Marwari, Yadav and Khada (2009) in crossbred of local x Sirohi and Rao et al., (2009) in Ganjam goats respectively. On the contrary higher WFC than that observed in present study were reported by Patel (2005) in Parbatsari, Kumar et al., (2006) in Kutchi, Maroof et al., (2007) in Beetal and Dudhe et al., (2015) in Sirohi goats respectively.

\section{Age at first kidding (AFK)}

The overall least squares means for age at first kidding was estimated as $594.88 \pm 13$.05days (Table 1). The finding are in close agreement with the values reported by Pathodiya (2004) in Sirohi, Rai and Singh (2005) in Jakhrana and Yadav et al., (2017) in Sirohi goats. However the lower estimates were reported by Pathodiya (2003) in Sirohi, Hassan et al., (2010) in Jamunapari, Ekambaram et al., (2011) in Mahabubnagar and Dash and Sethi (2017) in Raighar goats respectively. Comparatively higher values were reported by Pathodiya (2005) in Sirohi, Swami et al., (2006) in Sirohi $\times$ Beetal crosses, Singh et al., (2009) in Mehsana and Dudhe et al., (2015) in Sirohi goats respectively.

Table.1 Means $( \pm$ SE) for age at first conception and kidding in Sirohi goats

\begin{tabular}{|c|c|c|c|}
\hline & 268 & \multicolumn{2}{|c|}{ Mean \pm SE } \\
\hline & & Age at first conception $(\mathbf{k g})$ & Age at first kidding (kg) \\
\hline Overall mean $(\boldsymbol{\mu})$ & & $444.18 \pm 13.05$ & $594.88 \pm 13.05$ \\
\hline Cluster & & $*$ & $*$ \\
\hline Farm & 59 & $417 \pm 13.05^{\mathrm{a}}$ & $568.74 \pm 23.04^{\mathrm{a}}$ \\
\hline Field & 209 & $470 \pm 23.05^{\mathrm{b}}$ & $621.01 \pm 12.24^{\mathrm{b}}$ \\
\hline
\end{tabular}

Means with different superscript within the columns differ significantly $(\mathrm{P}<0.05)$ with each other

Table.2 Means $( \pm$ SE) for weight at first conception and kidding in Sirohi goats

\begin{tabular}{|c|c|c|c|}
\hline & 268 & \multicolumn{2}{|c|}{ Mean \pm SE } \\
\hline $\begin{array}{c}\text { Everall mean } \\
(\mu)\end{array}$ & & weight at first conception (kg) & weight at first kidding (kg) \\
\hline Cluster & & $26.77 \pm 0.21$ & $30.90 \pm 0.18$ \\
\hline Farm & 59 & $* *$ & $* *$ \\
\hline Field & 209 & $26.08 \pm 0.38^{\mathrm{a}}$ & $30.40 \pm 0.17^{\mathrm{a}}$ \\
\hline
\end{tabular}

Means with different superscript within the columns differ significantly $(\mathrm{P}<0.01)$ with each other 


\section{Weight at first kidding (WFK)}

The overall least squares means for weight at first kidding was estimated as $30.90 \pm 0.18 \mathrm{~kg}$ (Table 2). The present falls in close range with the results reported by Kumar et al., (2005) in Sirohi goats. The present estimates were higher than the results reported by reported by Kumar et al., (2012) in Sirohi, Rao et al., (2009) in Ganjam, Patel and Pandey (2013) in Sangamneri and Dash and Sethi (2017) in Raighar goats respectively. Whereas, lower than that reported by Dudhe et al., (2015) in Sirohi goats.

\section{Effect of cluster}

The present study revealed that the clusterwise variation was significant $(\mathrm{P} \leq 0.05)$ on age at first conception and age at first kidding. Whereas, highly significant $(\mathrm{P} \leq 0.01)$ on weight at first conception and weight at first kidding. The findings corroborated with the results reported by Dudhe et al., (2015) who observed highly significant $(\mathrm{P} \leq 0.01)$ effect on weight at first conception and weight at first kidding, significant $(\mathrm{P} \leq 0.05)$ effect on age at first conception and age at first kidding, yadav et al., (2017) reported highly significant $(\mathrm{P} \leq 0.01)$ on age at first conception and age at first kidding in Sirohi goats. Singh et al., (2009) reported significant $(\mathrm{P} \leq 0.05)$ effect on age at first conception in Mehsana goats. Ekambaram et al., (2011) reported significant $(\mathrm{P} \leq 0.05)$ effect on age at first conception and age at first kidding in Mahabubnagar goats and Hasan et al., (2014) in Black Bengal. He also reported nonsignificant effect on age at first conception in Black Bengal and Rawat et al., (2017) on age at first kidding in Bundelkhandi goats. Age at first conception was lowest in farm cluster than field cluster. It indicates that animals in farm cluster get early sexual maturity than field cluster. This variation might be due to more stressful conditions and lower heat detection at field cluster. Likewise age at first kidding was lowest in farm cluster than field cluster. Whereas, highest weight at first conception and weight at first kidding observed in present study was in field cluster than farm cluster. The present findings indicate that influence of the cluster might be attributed to the variations in feeding, housing and health care management.

This study concludes that goats can be reared under farm and field conditions with improved feeding and better management practices may help in better reproductive performances of Sirohi goats, which can be profitable at rural areas in Rajasthan. In order to optimize the productive potential of goat, it is essential that reproductive management programme should be implemented for improvement of reproductive aspects of goat. This study can be beneficial for those who are interested to establish goat farm in the rural areas of Rajasthan, which may help in alleviating poverty.

\section{Acknowledgements}

We thank the people who cordially cooperated by providing valuable information to accomplish this research work.

\section{References}

Animal Husbandry Rajasthan 2016. http://www.animalhusbandry.rajasthan. gov.in

Dash, S K., and Sethi, B P. 2017. Genetic studies on reproduction performance of Raighar goat in its native tract. Integrative Journal of Veterinary Biosciences, 1(1): 1-4.

Deokar, D K., Lawar, V S., Pawar, B K., and Andhale, R R. 2007. Breed characteristics of Sangamneri goat. 
Indian Journal of Small Ruminants, 13(2): 213-215.

Dudhe, S D., 2015. Studies on Growth, Productive and Reproductive Performance of Sirohi Goats around Udaipur District of Rajasthan under Field Condition, Rajasthan, India. Ph.D. Thesis, Rajasthan University of Veterinary and Animal Science, Bikaner, India.

Ekambaram, B., Gupta, B R., Prakash, M G., Sudhaker, K., and Reddy, V R. (2010). A study on the performance of Mahabubnagar goats. Indian Journal Animal Research, 44 (1): 48-51.

Harvey, W R. 1990. User's Guide for LSMLW and MIXMDL PC-2 Version. Mixed model least-squares and maximum likelihood computer program. Ohio State University, Columbus, Ohio. U.S.A.

Hassan, M R., Talukder, M A I., and Sultana, S. (2010). Evaluation of the production characteristics of the Jamunapari goat and its adaptability to farm conditions in Bangladesh. The Bangladesh Veterinarian, 27 (1): 26-35.

Khan, H., Muhammad, F., Ahmad, R., Nawaz, G., Rahimullah, A., and Zubair, M. 2006. Relationship of body weight with linear body measurements in goats. Journal of Agriculture and Biological Science, 1: 51-54.

Kumar, A., Kumar, S., Mishra, A K., and Singh, V K. 2006.Characteristics of Kutchi goats of Gujarat. Indian Journal Small Ruminants, 12 (2): 162-168.

Kumar, A., Singh, U., Tomar, A K S., Mehta, B S. 2005. Factor affecting reproductive traits in Sirohi goats at organized farm. Proceedings of VIII National Conference on Animal Genetics and Breeding, 411(6): 49.

Kumar, U., Nagda, R K., Sharma, S K. 2012. Reproductive status of Sirohi goats under field conditions. Indian Journal of Small Ruminants, 18 (1): 143-144.

Maroof, A., Singh P K., Sadana, D K., Alam, S., and Chahal, D. 2007. Reproductive performance of Beetal goats in its breeding tract. Indian Journal of Small Ruminants, 13(2): 182-185

Patel, A C., Pandey, D P. 2013. Growth, production and reproduction performance of Mehsana goat. Journal of Livestock Science, 4: 17-21

Patel, A K., Mathur, B K and Kaushish, S K. 2005. Kidding performance of arid goat breeds under different management systems. Indian Journal of Small Ruminants 11(2): 140-144

Pathodiya, O P. 2004. Annual Report (20032004) of AIRCP on Goat Improvement (Sirohi Field Unit) Livestock Research Station, Vallabhnagar, Maharana Pratap University of Agriculture \& Technology, Udaipur.

Pathodiya, O P., Tailor, S P., and Nagda, R K. 2003. Annual Report (2002-2003) of AIRCP on Goat Improvement (Sirohi Field Unit) Livestock Research Station, Vallabhnagar, Maharana Pratap University of Agriculture \& Technology, Udaipur.

Rai, B., Singh, M K., Khan, B U. and Yadav, M C.2004. Factors affecting growth traits in Marwari Goats. Indian Journal Animal Sciences, 74(5): 543-546

Rao, P K., Dash, S K., Singh, M K., Rai, B., and Singh, N. P. 2009. Ganjam goat of Orissa and its management practices. Indian Journal of Small Ruminants, 15(1): 44-50

Rawat, S K., Narain, S., and Tyagi, S P. 2017. Performance of Bundelkhandi Goat in Terms of Productive and Reproductive Traits in Mahoba District of Uttar Pradesh. Indian Research Journal of Extension Education. January 2017 (Special issue on Veterinary Research $\&$ Extension). 
Sabapara, G P., Deshpande, S B., Singh, G., and Joshi, B K. 2010. Reproduction and production performance of Surti goats in its native tract. Indian Journal of Small Ruminants, 16(2): 195-198.

Singh, K P., Dixit, S P., Singh, P K., Pandey, D P., and Ahlawat, S P S. 2009. A note on growth and reproduction traits of Mehsana goats under farmer's flocks. Indian Journal of Small Ruminants, 15(2): 271-273.

Swami, P D., Barhat, N K., Joshi, R K., Murdia, C K., and Kumar V. 2006. Reproductive performance of Sirohi goats and itscrosses with Beetal in
Semi-arid condition of Rajasthan. Indian Journal of Animal Sciences, 76 (4): 346-348.

Yadav, C M., and Khada, B S. 2009. Management practices and performance of goats in tribal belt of Dungarpur district in Rajasthan. Indian Journal of Small Ruminants, 15(1): 131-133.

Yadav, M C., Kumar, A., Jinger, S C., Lawania, P., Bugalia, H L., Jatolia, P. 2017. Reproductive performance of Sirohi goat flock under field condition. International Journal of Current Microbiology and Applied Sciences, 6(10): 4704-4708.

\section{How to cite this article:}

Hina Ashraf Waiz, Lokesh Gautam, Mukesh Chand Sharma and Syma Ashraf. 2018. Study of Female Reproductive Performance of Sirohi Goat Managed under Farm and Field Cluster in Southern Rajasthan, India. Int.J.Curr.Microbiol.App.Sci. 7(06): 885-890.

doi: https://doi.org/10.20546/ijcmas.2018.706.104 